\title{
Assessment of regional-level long-term gridded rainfall variability over the Odisha State of India
}

\author{
A. K. Prabhakar ${ }^{1}$ K. K. Singh ${ }^{1}$ - A. K. Lohani ${ }^{2}$ 'S. K. Chandniha ${ }^{3}$
}

Received: 25 June 2018 / Accepted: 5 May 2019 / Published online: 14 May 2019

(c) The Author(s) 2019

\begin{abstract}
Odisha State is located in eastern part of India which is blessed with sufficient amount of rainfall. Major part of the state is covered by Mahanadi river basin; Mahanadi river basin originated from Sihawa town and disposed out to Bay of Bengal near Sambalpur, Odisha State. The distribution pattern is erratic and uneven due to climate, topography, hydrology and geomorphology of the state. Catchment area of the Mahanadi is vast; therefore, drainage order is also high (about six); due to these features large amount of water has generated, and it will be appeared as flood at downstream through deltaic region to Bay of Bengal. In this connection, water resources planning and management are one of the crucial issues. For any hydrological study, it is necessary to identify the characteristics and climatic variability of the catchment. In the present study, long-term (1901-2013) rainfall time series has been utilized for rainfall variability analysis using nonparametric tests, viz. Mann-Kendall (MK), modified Mann-Kendall (MMK) and Theil-Sen's slope. The average annual rainfall of the Odisha State is to be found as about $1438 \mathrm{~mm}$; out of them, about $78 \%$ occurs in the monsoon season. In the present study, it was found that the maximum and minimum rainfalls occurred at Bhadrak and Puri districts, respectively. As per change point detection, it was found to be as 1945 is shift change year. Further, it was noticed that most of the districts are showing positive trends before change point and vice versa. Similar results are estimated in the monsoon season because most of the rainfall has occurred in the monsoon season. Both positive and negative trends have been found in Odisha State; detailed study has been carried out for rainfall behavior identification of the state. The present study is useful for agricultural and water resources planning and mitigation.
\end{abstract}

Keywords Mann-Kendall $\cdot$ Modified Mann-Kendall test $\cdot$ Rainfall variability $\cdot$ IMD gridded data

\section{Introduction}

Increase in water demand with an increase in population in India along with improvement in quality of life and climatic variability has attracted the attention of scientist and engineers to estimate availability of water at a place for sustainability. The primary source for river flow in India is rainfall. Extreme variability in rainfall could result in extreme hydrological events such as drought and floods (Kalra and Ahmad

A. K. Prabhakar

ajayprabhakar2@gmail.com; akprabhakar@nitkkr.ac.in

1 Department of Civil Engineering, National Institute of Technology, Kurukshetra, India

2 Surface Water Hydrology Division, National Institute of Hydrology, Roorkee, Uttarakhand, India

3 Department of Soil and Water Engineering, Indira Gandhi Krishi Vishwavidyalaya, Raipur, Chhattisgarh, India
2012). Deficiency in rainfall from average annual rainfall of the area has an ultimate impact on agricultural produce. More than $60 \%$ of India's population is based on agriculture which generates about $20 \%$ of the national gross domestic product (GDP). The climate changes in recent years have led to more variability in rainfall pattern. However, the effect is not uniform throughout the Earth.

The uncertainty and non-uniformity associated with rainfall characteristics could result in severe impact on agricultural production in India as the farmers mostly depend on rainfall. Therefore, precipitation is an essential variable along with other hydro-climatic variables, viz. temperature, evapotranspiration and humidity (Chowdhury et al. 2014). Thus, there is an acute need to study the changed rainfall patterns and its effect on water resources. Available literature associated with global warming effects strongly indicates that at global scale there are significant changes in rainfall pattern (Diaz et al. 1989; Hulme et al. 1998). Various other 
authors (Rind et al. 1989; Mearns et al. 1996) have also highlighted the future climate changes and its influence on rainfall trends. Studies analyzing rainfall characteristics, variability and trends have reported that there will be extreme variations in precipitation intensity, spatial and temporal rainfall patterns in most regions of India (Goswami et al. 2006; Kumar et al. 2010) and China (Wang and Zhou 2005) in future.

Various authors (Mirza 2002; Goswami et al. 2006; Dash et al. 2007) reported that many parts of Asia would witness an increase in intense rainfall events, while a reduction in the total rainy days and total annual rainfall. Studies based on daily values of rainfall from 1951 to 2000 reported the rising trends in magnitude and frequency of extreme events of precipitation as well as noticeably decrease in the frequency of the usual occurrences (Goswami et al. 2006) during the monsoon over central India. Mirza et al. (1998) conducted an extensive analysis of Ganga and Brahmaputra river basins and reported that in Ganga basin rainfall pattern shows stability largely, while Brahmaputra basin shows increasing rainfall pattern. A study of annual rainfall of nine river basins of central India and northwest (Singh et al. 2008) indicated increasing trend in annual rainfall in the majority of the basins. For the entire northwest and central India, the annual rainfall increased by $5.2 \%$ of mean per 100 years. Sinha Ray and De (2003) found that all-India rainfall shows no significant trend, except for some periodic behavior. Sinha Ray and Srivastava (1999) established that the frequency of heavy rainfall events during the southwest monsoon shows an increasing trend over certain parts of India. However, a decreasing trend has been observed during winter, pre-monsoon and post-monsoon seasons.

Gradual or abrupt (steep change) in trend or more complex spatial and temporal variations may occur in rainfall (Kundzewicz and Robson 2004). Such changes will affect statistical properties (mean, median, variance, kurtosis, skewness, autocorrelation, etc.) of rainfall with time. The difference in observational process and natural climatic phenomena may result in sudden or gradual changes in climatic variables. From the latest Intergovernmental Panel on Climate Change (IPCC) report, it has been observed that massive precipitation events are likely to increase disproportionately in comparison with mean differences between the years 1951 and 2003 for many midlatitude regions. Also, the reduction in the total annual precipitation is reported by Liuzzo et al. (2015). Based on the study of monthly rainfall data series of 135 years in 30 subdivisions (regions) in India from the year 1871-2005, Kumar et al. (2010) reported rising trends in annual precipitation in $50 \%$ of the subdivisions. Mondal et al. 2012 have found rising and decreasing trend of precipitation in months in Cuttack District, Odisha.

Based on mathematical tools/methods, the works reported for rainfall trend analysis may be grouped into two types (Zhang et al. 2006; Kundzewicz and Robson 2004). The first method is named as a parametric method (linear and residual models), while the second is termed as a nonparametric method (Mann 1945; Kendall 1975b), viz. Mann-Kendall (MK), modified Mann-Kendall (MMK) and the Sen's slope estimator (1968). Out of these methods, the use of a nonparametric approach (Kalumba et al. 2013; Sabzevari et al. 2015) is more appropriate for an analysis of distributed data involving uncertainty, which is observed in hydrometeorological time series. Sen (1968) extended the work reported by Thiel (1950) and developed a procedure unaffected by outliers and gross data errors which are called as Sen's slope estimator. Several researchers (Yu et al. 1993; Yue and Hashino 2003; Palizdan et al. 2015; Chandniha et al. 2016; Prabhakar et al. 2017; Mondal et al. 2018) reported their works regarding detecting a hydrological and hydrometeorological trend in the time series by the MK test and Sen's slope estimator.

In this study, MK/MMK test method and Sen's slope estimator for 30 districts of the state have been used for trend analysis of the long-term rainfall record of Odisha, India, available from the year 1901 to 2013 on the annual and seasonal basis. Different seasons considered for study are monsoon, pre-monsoon, post-monsoon and winter. Standard normal homogeneity test (SNHT) and Mann-Whitney-Pettitt (MWP) test are used to investigate the change point in the long-term rainfall time series. The annual and seasonal rainfall variability, viz. coefficient of variation (CV), including cross- and autocorrelations have also been examined for the time series.

\section{Study area and data availability}

The geographical area of Odisha State is about $156,077 \mathrm{~km}^{2}$, which has 30 districts. The gridded (resolution of $0.25^{\circ}$ latitude $\times 0.25^{\circ}$ longitude) daily rainfall data for the study have been procured from Indian Meteorological Department (IMD), Pune, from the year 1901 to 2013. The long-term rainfall of the state varies between 961 and $1872 \mathrm{~mm}$. However, the normal annual rainfall of the state is about $1438 \mathrm{~mm}$. The overall weather of the Odisha State is highly humid with medium-to-high rainfall, tropical and short winter with mild temperature. The varying intensities of cyclones, drought and flood occur almost every year in most of the districts. The maximum temperature in summer season goes above $40{ }^{\circ} \mathrm{C}$ hovering between 40 and $46{ }^{\circ} \mathrm{C}$ in western districts, viz. Sundargarh, Sambalpur, Balangir, Kalahandi and Mayurbhanj. The minimum temperature goes down to $1.02{ }^{\circ} \mathrm{C}$. Figure 1 shows the map of Odisha State along with locations of 30 districts. 


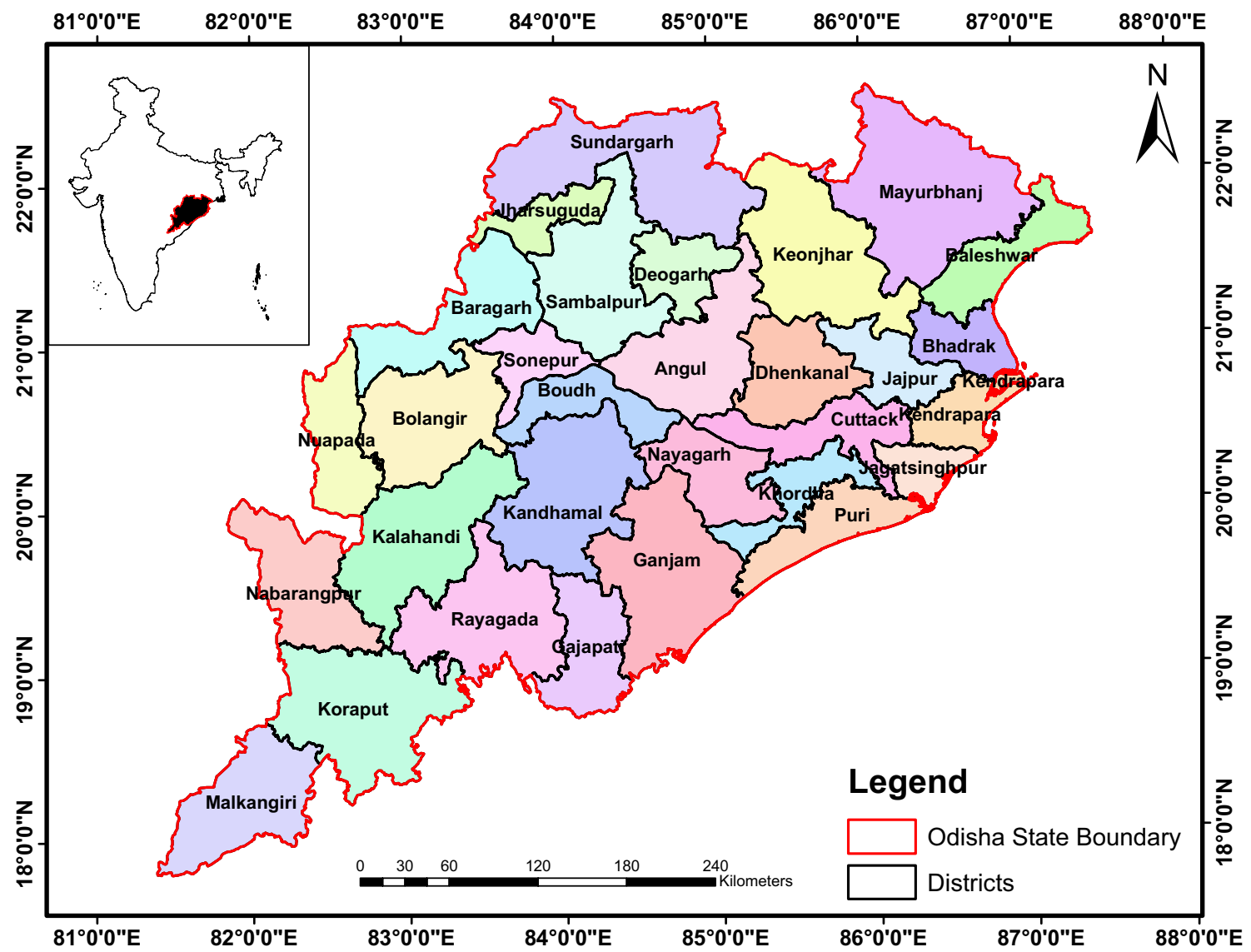

Fig. 1 Odisha State along with locations of 30 districts

\section{Methodology}

For investigating the spatial and temporal changes in rainfall, the whole year is categorized into different seasons, mainly winter (December-February), pre-monsoon (March-May), monsoon (June-September) and post-monsoon (October-November). IMD gridded (resolution of $0.25^{\circ}$ latitude $\times 0.25^{\circ}$ longitude) daily rainfall has been converted into weighted average rainfall time series for different districts of Odisha as per administrative boundary of the districts. The daily rainfall series are used to form monthly, seasonal and annual series for the trend analysis. The rainfall series varied spatially and temporally. Factors like instruments, observing practices, station environment situation and location of the station may impact the uniformity of rainfall data time series (Huang et al. 2015).

As discussed above, the long-term rainfall series may even have successive autocorrelations, and therefore, before conducting further investigations, the rainfall series is analyzed for homogeneity in time series by using SNHT. SNHT has been used for checking the homogeneity of long-term data series at $5 \%$ significance level
(Alexandersson 1986; Alexandersson and Moberg 1997). The critical values of SNHT test statics $\left(T_{0}\right)$ for various sample sizes (10-250) were initially developed using short Monte Carlo simulations with the different critical percentage (Khaliq and Ouarda 2007).

Further, MWP test was used to detect the possible breakpoint (Pettitt 1979) in long-term monthly data sets of each district of Odisha. After that, change percentages have been carried out from magnitude for both the data sets before and after breakpoint individually. Nonparametric MK and MMK tests have been used (Jain and Kumar 2012; Kendall 1975b; Kumar et al. 2010; Mann 1945) for the identification of monotonic trend as it is considered better than parametric tests (Kendall 1975a; Mann 1945). So in the present study, these tests have been used for the long-term rainfall trend analysis. The magnitude of trend has been quantified by Theil-Sen's estimator (Jhajharia et al. 2012; Tabari et al. 2011; Jain and Kumar 2012) found that different values of the magnitude of a trend in hydrometeorological time series. The relevant details of the foresaid tests and methods are summarized in the following sections. 


\section{Mann-Kendall (MK) test}

The MK statistical test requires sample data which should be serially independent (Yue and Wang 2004). The MK statistic, $S$, is defined as:

$S=\sum_{j=1}^{m-1} \sum_{k=j+1}^{m} \operatorname{sign}\left(x_{k}-x_{j}\right)$

where $x_{j}$ and $x_{k}$ are the $j$ th and $k$ th term in the sequential data of sample size $\mathrm{m}$ and for $x_{k}-x_{j}=\theta$

$\operatorname{Sign}(\theta)= \begin{cases}1 & \text { if } \theta>1 \\ 0 & \text { if } \theta=0 \\ -1 & \text { if } \theta<1\end{cases}$

Assuming independent data with identically scattered, the variance and mean of the $S$ statistic in Eq. (2) may be calculated as given by (Kendall 1975a; Dinpashoh et al. 2011):

$E[S]=0, \quad \operatorname{Var}(S)=\frac{m(m-1)(2 m+5)}{18}$.

However, for ties in the data set the expression for $\operatorname{Var}(S)$ becomes:

$\operatorname{Var}(S)=\frac{m(m-1)(2 m+5)-\sum_{i=1}^{m} t_{i}\left(t_{i}-1\right)\left(2 t_{i}+5\right)}{18}$,

where $m$ is the number of tied (zero difference between compared values) groups and $t_{i}$ is the number of data points in the $i$ th tied group. The standard normal deviate ( $Z$ statistics) is then computed

$Z= \begin{cases}\frac{S-1}{\sqrt{\operatorname{Var}(S)}} & \text { if } S>0 \\ 0 & \text { if } S=0 \\ \frac{S+1}{\sqrt{\operatorname{Var}(S)}} & \text { if } S<0\end{cases}$

The $Z$ values greater than \pm 1.96 represent $5 \%$ level of significant positive/negative trend in the time series, respectively.

\section{Modified Mann-Kendall (MMK) test}

The modified variance of $S$ is used in MMK statistical test for minimizing the influence of significant autocorrelation coefficients from the time series as reported by the authors (Hamed and Rao 1998). The modified spatial and temporal variance of $S$, labeled as $\operatorname{Var}(S)^{*}$, is expressed as follows:

$\operatorname{Var}(S)^{*}=\operatorname{Var}(S) \frac{m}{m^{*}}$, where $m^{*}=$ adequate sample size. Based on the work reported by Hamed and Rao (1998), the $m / m^{*}$ ratio may be defined as

$\frac{m}{m^{*}}=1+\frac{2}{m(m-1)(m-2)} \sum_{i=1}^{m=1}(m-1)(m-i-1)(m-i-2) r i$,

where $m=$ actual number of sample data and $r i=$ lag- $i$ represents the significant autocorrelation coefficient of rank $I$ of time series. The computed values of $\operatorname{Var}(S) *($ Eq. 5) are used for the $\operatorname{Var}(S)$ in Eq. (3). The results are compared with threshold levels at $5 \%$, and the values above \pm 1.96 are significant level.

\section{Theil-Sen's slope estimator}

Sen (1968) gave nonparametric procedure for a linear trend in time series in terms of slopes. The slope estimates $\left(Q_{i}\right)$ of $\mathrm{m}$ pairs of data are calculated using the following expression as:

$Q_{i}=\frac{x_{j}-x_{k}}{j-k} \quad$ for $\quad i=1,2,3, \ldots, m$.

The median of $Q_{i}$ is derived from:

$\beta=\left\{\begin{array}{ll}Q(m+1) / 2 & m \text { is odd } \\ \frac{1}{2}(Q m / 2+Q(m+2) / 2) & m \text { is even }\end{array}\right.$.

The results are compared with threshold levels at $5 \%$, and the $\beta$ values above \pm 1.96 are significant (increasing/decreasing) trends.

\section{Mann-Whitney-Pettitt test}

The sample time series $X=\left(x_{1}, x_{2}, \ldots, x_{m}\right)$, partition $X$ such that $Y=\left(x_{1}, x_{2}, \ldots, x_{m 1}\right)$ and $Z=\left(x_{m 1+1}, x_{m 2+1}, \ldots, x_{m 1+m 2}\right)$. The Mann-Whitney-Pettitt test statistics are given as

$Z_{c}=\frac{\sum_{t=1}^{m 1} r\left(x_{t}\right)-m_{1}\left(m_{1}+m_{2}+1\right) / 2}{\left[m_{1} m_{2}\left(m_{1}+m_{2}+1\right) / 12\right]^{1 / 2}}$,

where $r\left(x_{t}\right)$ is the rank of observations. The null hypothesis $H_{\mathrm{o}}$ is accepted if $-Z_{1-\alpha / 2} \leq Z_{c} \leq Z_{1-\alpha / 2}$, where $\pm Z_{1-\alpha / 2}$ are the $1-\alpha / 2$ quantiles of standard normal distribution corresponding to significance level $\alpha$ for the test.

\section{Standard normal homogeneity test (SNHT)}

The SNHT test (Alexandersson 1986) is used to detect a change in a rainfall time series, viz. $R(s)(s=1, \ldots, n)$. The time series $R(s)$ to compare the mean value of the initial $\mathrm{s}$ years of the record with that of last $n-s$ years is: 
$R(s)=s \bar{z}_{1}^{2}+(n-s) s \bar{z}_{2}^{2}$,

where

$\bar{z}_{1}=\frac{1}{s} \sum_{i=1}^{s} \frac{\left(Y_{i}-\bar{Y}\right)}{\sigma_{R}} \quad$ and $\quad \bar{z}_{2}=\frac{1}{n-s} \sum_{i=s+1}^{s} \frac{\left(Y_{i}-\bar{Y}\right)}{\sigma_{R}}$.

If any break point exists in $S$ year in the time series, then $R(s)$ approaches its maximum nearly at $s=S$. This test result, $R(s)$, is illustrated in the graphs. The test statistic To is defined as:

$T o=\max _{1 \leq s<n} R(s)$.

\section{Coefficient of variation (CV\%)}

The coefficient of variation (CV) statistically measures relative variability in the time series. It shows the individual data position differing from the mean value. Higher values of CV specify the high variability. The annual and seasonal rainfall variability (CV\%) (Landsea and Gray 1992) has been investigated for 30 districts of the Odisha State from the entire time series by the inverse distance weighted (IDW) technique in Arc-Map 9.3 which is shown in Fig. 2.

\section{Results and discussion}

The annual and seasonal rainfall for 113 years of the state has been analyzed. The statistical parameters such as mean, standard deviation (SD) and coefficient of variations (CV) have been estimated using Excel.

\section{Rainfall characteristics during the years 1901-2013}

The average annual rainfall of the state is found as $1438 \mathrm{~mm}$ with a minimum value of $961 \mathrm{~mm}$ and a maximum value of $1872 \mathrm{~mm}$. The standard deviation is approximately $190 \mathrm{~mm}$. Seasonal rainfall values range from 40 to $376 \mathrm{~mm}$ with SD of $54 \mathrm{~mm}$ (pre-monsoon); 750-1532 mm with SD of $155 \mathrm{~mm}$ (monsoon); 16-440 mm with SD of $96 \mathrm{~mm}$ (post-monsoon); and $1-141 \mathrm{~mm}$ with SD of $31 \mathrm{~mm}$ (winter). This statistic indicates that the regions with more rainfall have less variability than the areas with relatively lower rainfall. Monthly rainfall characteristics for Odisha State (1901-2013) are shown in Table 1. These rainfall characteristics represent that how much rainfall will probably be available and their confidence level could be used in deciding the cropping pattern.

The mean annual rainfall at different confidence levels, viz. 75, 90 and 95\%, has been computed for different districts of Odisha State. These confidence levels may be useful in deciding the cropping pattern, planning of agricultural practices, industrial and domestic uses and other water resource needs. The highest rainfall occurs in Bhadrak District with average magnitude $=1610.9 \mathrm{~mm}$, and the lowest rainfall in Puri District with average magnitude $=1139.9 \mathrm{~mm}$. The average annual rainfall at 75,90 and $95 \%$ of confidence level is found in Bhadrak District as 1339.3, 1195.2 and $1098.0 \mathrm{~mm}$, respectively. In Puri District, these are 973.1, 841.0 and $753.3 \mathrm{~mm}$, respectively. These values for all districts are shown in Fig. 3.

\section{The change point detection in the time series}

Homogeneity test has been applied to the time series using SNHT with the significance level of 5\% (Alexandersson 1986; Alexandersson and Moberg 1997). $H_{0}$ represents the homogeneous series, and $H_{\mathrm{a}}$ represents the heterogeneous series. The change point ( $P$ values) has been obtained after 10,000 Monte Carlo simulations. Considerable change or shift point in series has been detected by both MWP and SNHT tests. The change point years in Odisha using MWP and SNHT tests are shown in Table 2. These two analyses indicated that the year 1945 is the most likely change point year in time series for the state. The possible reason for the change in rainfall pattern from the year 1945 onwards is due to the beginning of current warming period (around 1950) from the past cooling period (1891-1950) (Mohanty et al. 2012).

\section{The rainfall season-wise autocorrelation analysis of Odisha State}

Autocorrelation analysis of the state has been done by varying lag from 1 to 24 . Figure $4 \mathrm{a}-\mathrm{e}$ shows the lag number versus autocorrelation functions for annual rainfall, premonsoon, monsoon, post-monsoon and winter. Two autocorrelations have been found for the pre-monsoon season at lags 17 and 22. One autocorrelation exists for the monsoon season at lag 17. Similarly, one autocorrelation exists for the post-monsoon season at lag 11 . And three autocorrelations exist for the winter season at lags 9, 14 and 24. These significant autocorrelation coefficients would influence the $Z$ statistic values from MK and MKK tests.

\section{Rainfall trend analysis with seasonal and annual time steps}

Rainfall trend analysis has been performed for seasonal (premonsoon, monsoon, post-monsoon and winter) and annual data series consisting of all data from 1901 to 2013, data up to pre-change point year (1945) and data from change point year to 2013. $Z$ statistics have been estimated using MK and 

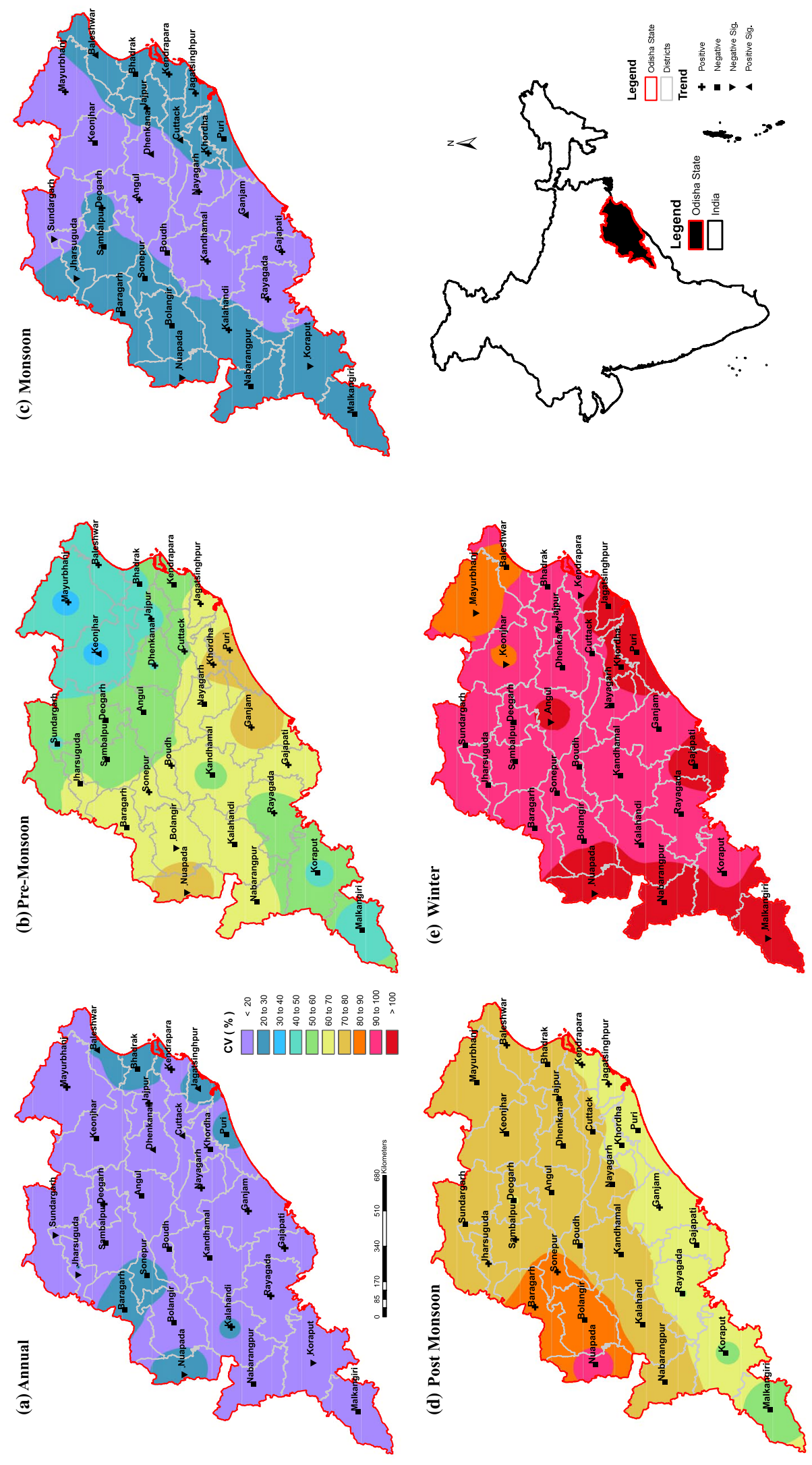

ôd 
Table 1 Monthly rainfall characteristics for Odisha State (1901-2013)

\begin{tabular}{lccrrrrr}
\hline Year & Mean $(\mathrm{mm})$ & SD $(\mathrm{mm})$ & $\mathrm{CV}(\%)$ & \multicolumn{1}{l}{$75 \%$} & $90 \%$ & $95 \%$ & $\begin{array}{c}\text { \% Contribu- } \\
\text { tion to annual }\end{array}$ \\
\hline \multicolumn{2}{l}{ Confidence } & level & & & & & \\
Jan & 12.3 & 15.4 & 125.0 & 0.1 & 0.0 & 0.0 & 0.9 \\
Feb & 21.7 & 24.5 & 113.2 & 1.6 & 0.1 & 0.0 & 1.5 \\
Mar & 21.2 & 22.9 & 108.1 & 2.8 & 0.3 & 0.0 & 1.5 \\
Apr & 32.1 & 22.9 & 71.3 & 12.1 & 4.9 & 3.0 & 2.2 \\
May & 65.6 & 43.2 & 65.9 & 33.5 & 20.3 & 14.0 & 4.6 \\
Jun & 204.0 & 75.9 & 37.2 & 132.6 & 95.8 & 79.2 & 14.2 \\
Jul & 335.5 & 88.9 & 26.5 & 249.7 & 197.9 & 174.0 & 23.3 \\
Aug & 341.7 & 82.6 & 24.2 & 258.4 & 208.4 & 179.2 & 23.8 \\
Sep & 239.3 & 66.2 & 27.7 & 177.5 & 136.4 & 117.9 & 16.6 \\
Oct & 126.0 & 84.6 & 67.2 & 53.0 & 28.0 & 19.1 & 8.8 \\
Nov & 33.4 & 44.5 & 133.4 & 1.1 & 0.1 & 0.0 & 2.3 \\
Dec & 5.9 & 12.2 & 207.5 & 0.0 & 0.0 & 0.0 & 0.4 \\
Annual & 1438.6 & 190.2 & 13.2 & 1251.9 & 1111.1 & 1029.5 & 100.0 \\
\hline
\end{tabular}

MMK tests at $5 \%$ of a significant level. Theil-Sen's slope has also been estimated using Eq. (8) for the state.

\section{Annual and seasonal rainfall analysis}

Results of $Z$ statistic values for all districts for annual and seasonal rainfalls are shown in Fig. 5. From the period 1901 to 2013, it is seen that in annual data the positive trend has been shown by 13 districts out of 30 and remaining districts show negative trend. At 5\% significance level, four districts, viz. Baleshwar, Cuttack, Dhenkanal and Jagatsinghpur, are having positive trend, four districts, viz. Jharsuguda, Koraput, Nuapada and Sundargarh, show negative trend and rest do not show any significant trend. Further, in premonsoon season, only negative trend has been obtained in all districts with two districts, viz. Balangir and Nuapada, having significant trend. For monsoon season, only four districts (Baleshwar, Cuttack, Dhenkanal and Ganjam) have significant positive trend. In post-monsoon, no significant trend has been found. In winter season also only negative trend has been obtained in all districts with six districts (Angul, Jajpur, Kendrapara, Keonjhar, Mayurbhanj and Nuapada) having significant negative trend.

Similarly, from the year 1901 to 1945 , it is seen that in annual data the positive trend has been shown by 27 districts out of 30 and remaining districts show negative trend. At 5\% significance level, eight districts, viz. Baleshwar, Bhadrak, Boudh, Jajpur, Jharsuguda, Kendrapara, Keonjhar and Sambalpur, are having positive significant trend.

Further, in pre-monsoon season, only negative trend has been obtained in all districts with three districts, viz. Cuttack, Keonjhar and Mayurbhanj, having significant trend. For monsoon season, nine districts, viz. Baleshwar, Bargarh,
Bhadrak, Boudh, Jajpur, Kendrapara, Keonjhar, Mayurbhanj and Nuapada, have significant positive trend. In post-monsoon season, six districts, viz. Baleshwar, Bhadrak, Jajpur, Kendrapara, Keonjhar and Sundargarh, have positive significant trend. In winter season, most of the districts showed negative trend with six districts having no significant trend.

Likewise, from the year 1946 to 2013 , it is seen that in annual data the positive trend has been shown by 23 districts out of 30 and remaining districts show negative trend. At 5\% significance level, three districts, viz. Cuttack, Dhenkanal and Jagatsinghpur, are having positive significant trend. Further, in pre-monsoon season, most of the positive trend has been obtained in all districts with three districts, viz. Cuttack, Gajapati and Jajpur, having positive significant trend. For monsoon season, six districts, viz. Cuttack, Deogarh, Dhenkanal, Gajapati, Ganjam and Jagatsinghpur, have significant positive trend and one district, viz. Jharsuguda, has significant negative trend. In post-monsoon, only negative trend has been obtained in all districts with one district, viz. Khordha, having significant negative trend. In winter season, there is no significant trend.

\section{Theil-Sen's slope for annual and seasonal rainfall}

The majority of the districts are showing negative trend from the analysis of annual rainfall series from the year 1901 to 2013. This suggests that availability of total rainfall is declining with years. This warrants special attention of water resources planner. However, within the year with different seasons there are both positive and negative variations, e.g., pre-monsoon rainfall shows increasing trend, whereas post-monsoon, monsoon and winter show decreasing trends. 

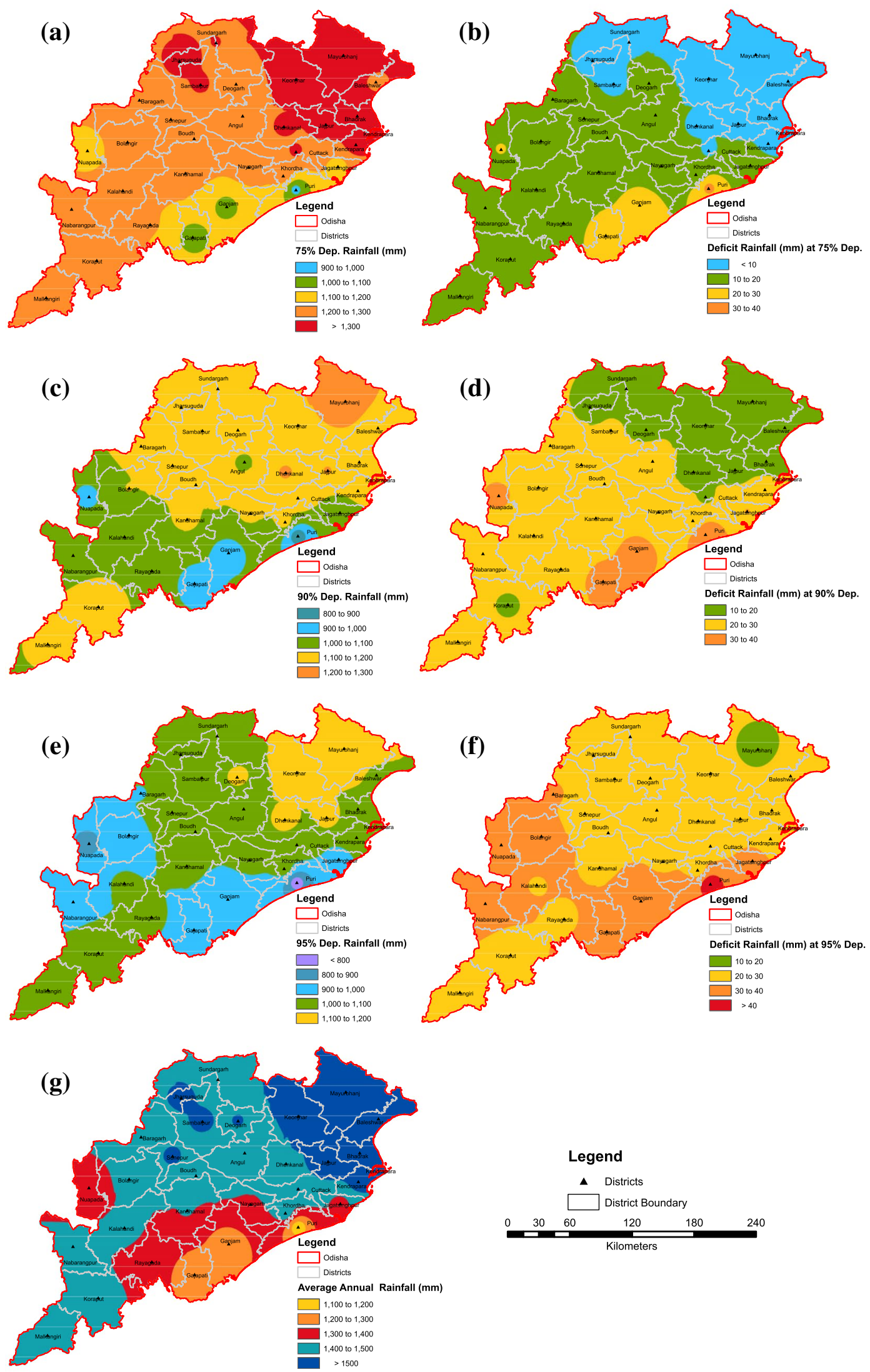
4Fig. 3 District-wise dependable rainfall and its deficit variability at different probability exceedance: a $75 \%$ dependable rainfall; $\mathbf{b}$ deficit rainfall at $75 \%$ level of confidence; c $90 \%$ dependable rainfall; d deficit rainfall at $90 \%$ level of confidence; e $95 \%$ dependable rainfall; $\mathbf{f}$ deficit rainfall at $95 \%$ level of confidence; $\mathbf{g}$ average annual rainfall during 1901-2013

Before change point years, it is seen that majority of the districts are showing positive trend from the analysis of annual rainfall series from the year 1901 to 1945. This suggests that availability of total rainfall is increasing with years. And within the year with different seasons there are both positive and negative variations, e.g., pre-monsoon and winter rainfalls show decreasing trend, whereas postmonsoon and monsoon show increasing trends.
After the change point years, it can be observed from the analysis that majority of the districts are showing less positive trend for the annual rainfall series from the year 1946 to 2013. This suggests that availability of overall rainfall is decreasing with years. However, within a year with different seasons there are both positive and negative variations, e.g., post-monsoon and winter rainfalls show decreasing trend, whereas pre-monsoon and monsoon show less increasing trends. The magnitude of change in rainfall trend is shown in Fig. 6 for different periods of analysis. The figure shows box plot of the Theil-Sen's slopes for monthly rainfall time series (a) 1901-2013; (b) 1901-1945; (c) 1946-2013; annual and seasonal rainfall time series (d) 1901-2013; (e) 1901-1945; (f) 1946-2013 of Odisha State. The central box line represents median, and the upper and lower lines
Table 2 Change point years in Odisha using MWP and SNHT tests

\begin{tabular}{|c|c|c|c|c|c|c|}
\hline \multirow[t]{2}{*}{ Districts/state } & \multicolumn{3}{|c|}{ MWP test } & \multicolumn{3}{|c|}{ SNHT test } \\
\hline & $P$ value & Year & Trend & To value & Year & Trend \\
\hline Angul & 0.34 & 1963 & $H_{\mathrm{o}}$ & 4.13 & 1963 & $H_{\mathrm{o}}$ \\
\hline Baleshwar & 0.15 & 1924 & $H_{\mathrm{o}}$ & 6.81 & 1912 & $H_{\mathrm{o}}$ \\
\hline Bargarh & 0.01 & 1961 & $H_{\mathrm{a}}$ & 11.63 & 1961 & $H_{\mathrm{a}}$ \\
\hline Bhadrak & 0.14 & 1952 & $H_{\mathrm{o}}$ & 8.41 & 1946 & $H_{\mathrm{o}}$ \\
\hline Balangir & 0.04 & 1961 & $H_{\mathrm{a}}$ & 5.12 & 1961 & $H_{\mathrm{o}}$ \\
\hline Boudh & 0.05 & 1944 & $H_{\mathrm{a}}$ & 8.37 & 1963 & $H_{\mathrm{o}}$ \\
\hline Cuttack & 0.01 & 1989 & $H_{\mathrm{a}}$ & 13.33 & 2000 & $H_{\mathrm{a}}$ \\
\hline Deogarh & 0.26 & 1982 & $H_{\mathrm{o}}$ & 4.76 & 1982 & $H_{\mathrm{o}}$ \\
\hline Dhenkanal & 0.00 & 1982 & $H_{\mathrm{a}}$ & 13.62 & 1982 & $H_{\mathrm{a}}$ \\
\hline Gajapati & 0.55 & 1977 & $H_{\mathrm{o}}$ & 4.27 & 1979 & $H_{\mathrm{o}}$ \\
\hline Ganjam & 0.46 & 1976 & $H_{\mathrm{o}}$ & 6.37 & 2012 & $H_{\mathrm{o}}$ \\
\hline Jagatsinghpur & 0.02 & 1989 & $H_{\mathrm{a}}$ & 10.32 & 1989 & $H_{\mathrm{o}}$ \\
\hline Jajpur & 0.21 & 1924 & $H_{\mathrm{o}}$ & 5.77 & 1924 & $H_{\mathrm{o}}$ \\
\hline Jharsuguda & 0.00 & 1952 & $H_{\mathrm{a}}$ & 14.68 & 1961 & $H_{\mathrm{a}}$ \\
\hline Kalahandi & 0.37 & 1989 & $H_{\mathrm{o}}$ & 6.52 & 2000 & $H_{\mathrm{o}}$ \\
\hline Kandhamal & 0.23 & 1963 & $H_{\mathrm{o}}$ & 4.47 & 1933 & $H_{\mathrm{o}}$ \\
\hline Kendrapara & 0.47 & 1912 & $H_{\mathrm{o}}$ & 5.18 & 1912 & $H_{\mathrm{o}}$ \\
\hline Keonjhar & 0.32 & 1946 & $H_{\mathrm{o}}$ & 4.00 & 1946 & $H_{\mathrm{o}}$ \\
\hline Khordha & 0.14 & 1989 & $H_{\mathrm{o}}$ & 6.31 & 1989 & $H_{\mathrm{o}}$ \\
\hline Koraput & 0.00 & 1962 & $H_{\mathrm{a}}$ & 10.34 & 1962 & $H_{\mathrm{o}}$ \\
\hline Malkangiri & 0.10 & 1959 & $H_{\mathrm{o}}$ & 11.14 & 2002 & $H_{\mathrm{o}}$ \\
\hline Mayurbhanj & 0.68 & 1970 & $H_{\mathrm{o}}$ & 5.76 & 2012 & $H_{\mathrm{o}}$ \\
\hline Nabarangpur & 0.26 & 1947 & $H_{\mathrm{o}}$ & 5.58 & 2002 & $H_{\mathrm{o}}$ \\
\hline Nayagarh & 0.08 & 1989 & $H_{\mathrm{o}}$ & 7.94 & 2000 & $H_{\mathrm{o}}$ \\
\hline Nuapada & 0.00 & 1961 & $H_{\mathrm{a}}$ & 14.35 & 1961 & $H_{\mathrm{a}}$ \\
\hline Puri & 0.31 & 1989 & $H_{\mathrm{o}}$ & 4.79 & 1989 & $H_{\mathrm{o}}$ \\
\hline Rayagada & 0.91 & 1913 & $H_{\mathrm{o}}$ & 2.86 & 1908 & $H_{\mathrm{o}}$ \\
\hline Sambalpur & 0.04 & 1946 & $H_{\mathrm{a}}$ & 7.51 & 1961 & $H_{\mathrm{o}}$ \\
\hline Sonepur & 0.11 & 1944 & $H_{\mathrm{o}}$ & 4.51 & 1944 & $H_{\mathrm{o}}$ \\
\hline Sundargarh & 0.00 & 1953 & $H_{\mathrm{a}}$ & 15.27 & 1953 & $H_{\mathrm{a}}$ \\
\hline Odisha State & 0.27 & 1945 & $H_{\mathrm{o}}$ & 3.96 & 1945 & $H_{\mathrm{o}}$ \\
\hline
\end{tabular}



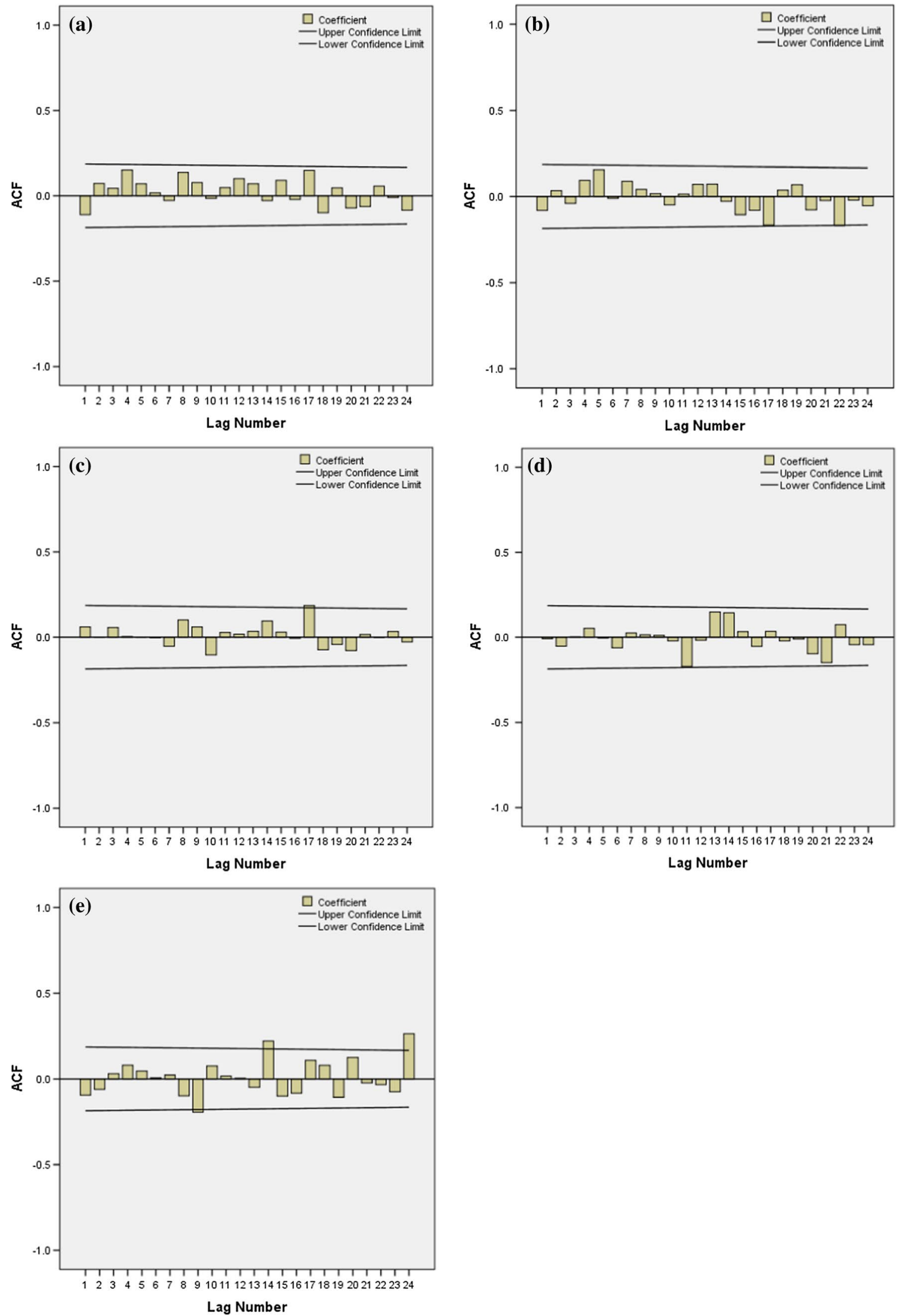

Fig. 4 Lag number versus autocorrelation functions (ACF) for time series of 113 years: a annual rainfall; b pre-monsoon; c monsoon; d postmonsoon; and e winter 

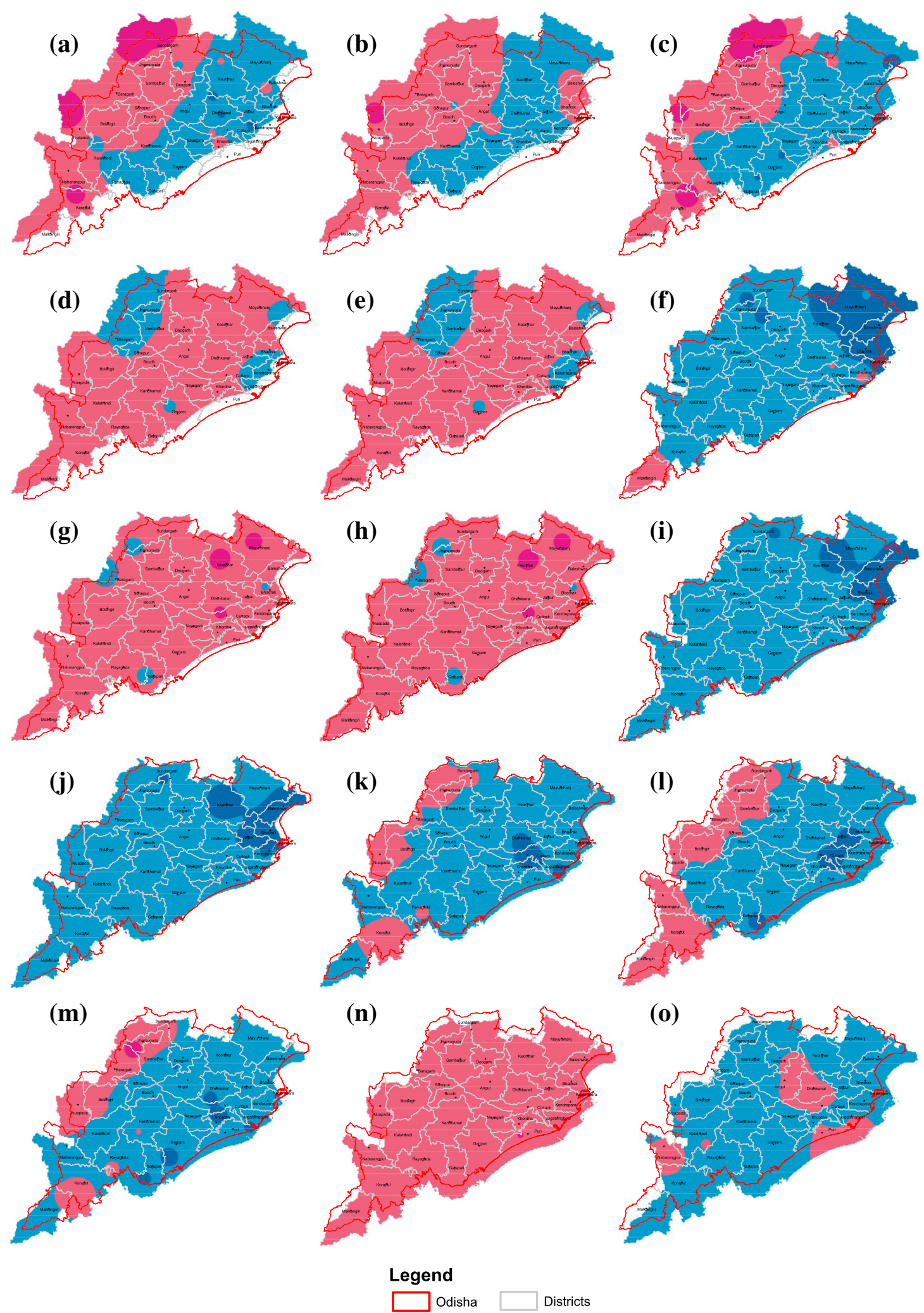

\section{Z-Statistics Value}

$<-1.96$ Significant Negative Trend -1.96 - 0 Negative Trend

0 - 1.96 Positive Trend

$>1.96$ Significant Positive Trend

Fig. $5 \mathrm{Z}$ statistic (MMK) values of annual, pre-monsoon, monsoon, post-monsoon and winter rainfall of all districts during 1901-2013 (a-e), 1901-1945 (f-j), and 1946-2013 (k-o) 

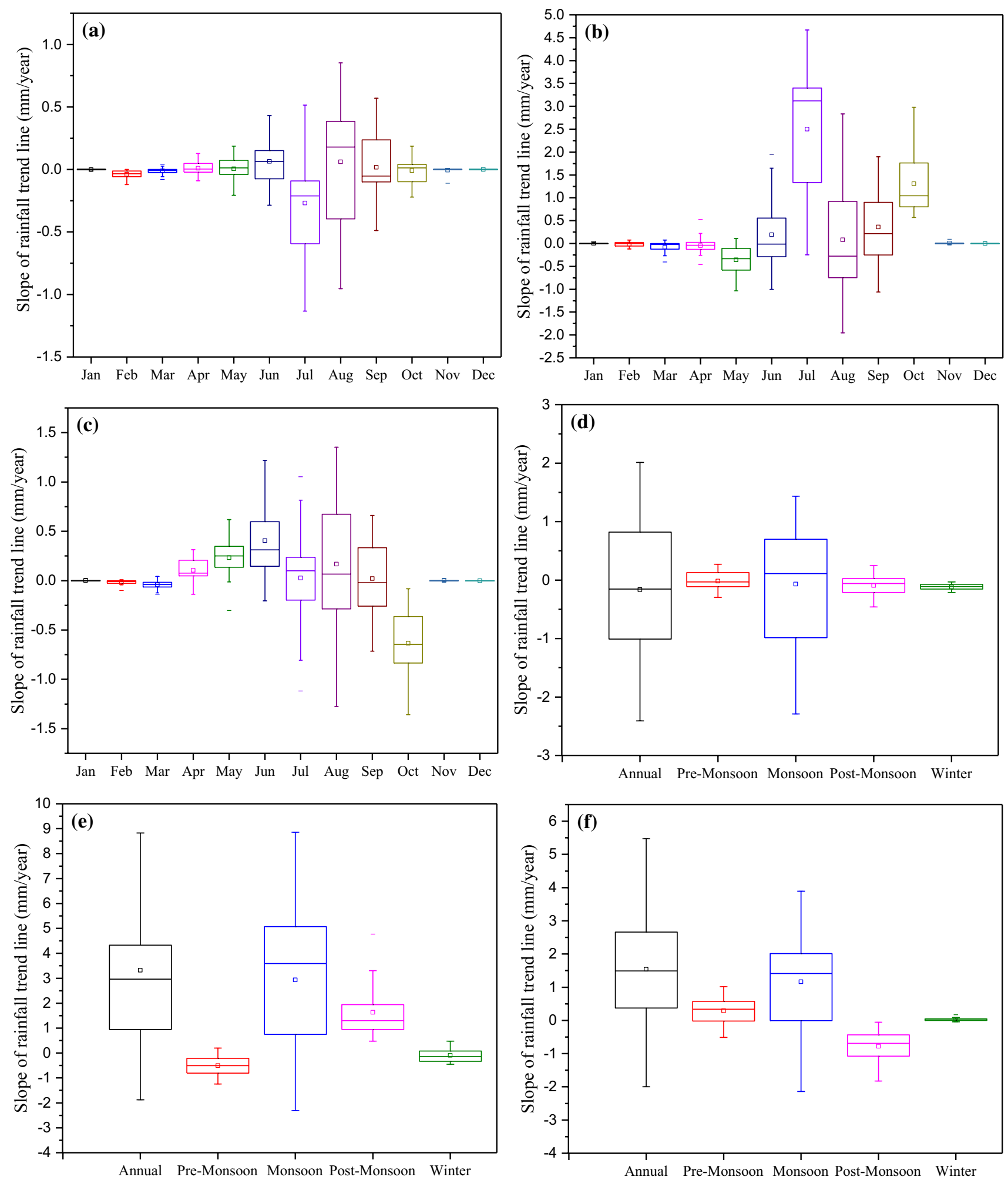

Fig. 6 Box plot of Theil-Sen's slope values for monthly rainfall time series during a 1901-2013; b 1901-1945; c 1946-2013; annual and seasonal rainfall time series d 1901-2013; e 1901-1945; f 1946-2013 over Odisha State 
rainfall events show the decrease trend in rainfall (Goswami et al. 2006). The deferential pressure generation due to the current warming period would also cause the uneven distribution of rainfall in most districts of Odisha State.

\section{Conclusion}

The following are the important conclusions derived from the study:

- The average annual rainfall of the state is found as $1438 \mathrm{~mm}$ with standard deviation of $\pm 190 \mathrm{~mm}$ with about $78 \%$ of rainfall in monsoon.

- The highest rainfall occurs in Bhadrak District with average magnitude of about $1610.9 \mathrm{~mm}$, and the lowest rainfall in Puri District with average magnitude of about $1139.9 \mathrm{~mm}$. The average annual rainfall at 75 , 90 and $95 \%$ of confidence level is found in Bhadrak District as $1339.3,1195.2$ and $1098.0 \mathrm{~mm}$, respectively.

- The year 1945 is the most likely change point year in time series for the state due to the beginning of current warming period. It is observed that the rainfall trend is having decreasing trend beyond this year.

- One autocorrelation exists for the monsoon season at lag 17. Similarly, one autocorrelation exists for the postmonsoon season at lag 11. And three autocorrelations exist for the winter season at lags 9, 14 and 24 .

- Annual rainfall is decreasing at 5\% significance level, with three districts, viz. Cuttack, Dhenkanal and Jagatsinghpur, having positive significant trend. Further, in pre-monsoon season, most of the positive trend has been obtained in all districts with three districts, viz. Cuttack, Gajapati and Jajpur, having positive significant trend. For monsoon season, six districts, viz. Cuttack, Deogarh, Dhenkanal, Gajapati, Ganjam and Jagatsinghpur, have significant positive trend and one district, viz. Jharsuguda, has significant negative trend. In post-monsoon, only negative trend has been obtained in all districts with one district, viz. Khordha, having significant negative trend. In winter season, there is no significant trend.

As the rainfall plays the most vital role in the hydrological analysis and water balance studies, the results of this study may provide useful inputs for the planning and management in context of agricultural and water resource areas.

Acknowledgements The authors are thankful to the India Meteorological Department for providing the rainfall data used in the study. We are also grateful to unknown reviewers for their useful suggestions for the improvement in this paper. represent the 75th and 25th percentile, respectively. Also, the upper and lower lines represent the maximum and minimum values of rainfall slopes.

\section{Discussion}

In this study, vast data have been processed for behavior identification long-term time series. Initially, entire daily time series has been extracted from IMD gridded data; further, it has been converted into monthly basis. Thereafter, it will be converted into weighted average rainfall time series and seasonal time series for each district. Change detection year has been found as 1945 . Hence, entire time series has been converted into two segments 1901-1945 and 1946-2013. Further, nonparametric trend analysis has been utilized, for all the time series 1901-2013, 1901-1946 and 1946-2013. In 1901-2013, most of the districts have been showing the negative trend in annual time series analysis, whereas in 1901-1945 and 1946-2013, it was noticed that most of the districts have been showing positive trends. Similar results were found by the various researchers at eastern region of India (Kumar et al. 1992; Patra et al. 2012; Mondal et al. 2015). In various places in India, it was found that the annual and monsoon time series having similar results in trend analysis even the level of significance is also matched (Patra et al. 2012; Chandniha et al. 2016; Pal et al. 2019). The insignificantly decreasing trends in pre-monsoon and post-monsoon rainfall are found in the majority of districts of Odisha during 1901-2013. Chandrasekhar (2010) suggested that the occurrence of temporary lows pressure over the eastern regions of India, and it would be the possible region of occurrence of rainfall in pre-monsoon seasons. The rainfall occurs from the moisture laden wind coming from Bay of Bengal during non-monsoon seasons through the differential pressure generated between the land sea areas. The rise in air temperature over the past decade may diminish the low-pressure zone over land area and would reduce the pre-monsoon and post-monsoon rainfall in most of the districts of Odisha State. On the other hand, the winter season showed the same pattern in rainfall (Jain and Kumar 2012; Warwade et al. 2018; Nema et al. 2018). Most of the districts of the Odisha State have shown the significant increasing rainfall trend in annual and monsoon rainfall for the period 1901-1945. The possible reason for the change in rainfall pattern from the year 1945 onwards is due to the beginning of current warming period (around 1950) from the past cooling period (1891-1950) (Mohanty et al. 2012). The air temperature rises more in the current warming period and would reduce the rainfall for the period 1946-2013. The magnitude and frequency of extreme rainfall events would increase, and moderate 
Open Access This article is distributed under the terms of the Creative Commons Attribution 4.0 International License (http://creativeco mmons.org/licenses/by/4.0/), which permits unrestricted use, distribution, and reproduction in any medium, provided you give appropriate credit to the original author(s) and the source, provide a link to the Creative Commons license, and indicate if changes were made.

\section{References}

Alexandersson $\mathrm{H}$ (1986) A homogeneity test applied to precipitation data. J Climatol 6(1):661-675

Alexandersson H, Moberg A (1997) Homogenization of Swedish temperature data. Part I: a homogeneity test for linear trends. Int J Climatol 17(1):25-34

Chandniha SK, Meshram SG, Adamowski JF, Meshram C (2016) Trend analysis of precipitation in Jharkhand State, India. Theor Appl Climatol 130:1-14

Chandrashekhar A (2010) Basics of atmospheric sciences. PHI Learning Pvt. Ltd., Delhi, pp 280-293

Chowdhury MR, Kumar VI, Sattar AB, Brahmachari KO (2014) Studies on the water use efficiency and nutrient uptake by rice under system of intensification. The Bioscan 9(1):85-88

Dash SK, Jenamani RK, Kalsi SR, Panda SK (2007) Some evidence of climate change in twentieth-century India. Clim Change 85(3-4):299-321

Diaz HF, Bradley RS, Eischeid JK (1989) Precipitation fluctuations over global land areas since the late 1800's. J Geophys Res D: Atmos 94(D1):1195-1210

Dinpashoh Y, Jhajharia D, Fakheri-Fard A, Singh VP, Kahya E (2011) Trends in reference crop evapotranspiration over Iran. J Hydrol 399(1):422-433

Goswami BN, Venugopal V, Sengupta D, Madhusoodanam MS, Xavier PK (2006) Increasing trends of extreme rain events over India in a warming environment. Science 314:1442-1445

Hamed KH, Rao AR (1998) A modified Mann-Kendall trend test for auto correlated data. J Hydrol 204:182-196

Huang D, Licuanan WY, Hoeksema BW, Chen CA, Ang PO, Huang $\mathrm{H}$, Yeemin T (2015) Extraordinary diversity of reef corals in the South China Sea. Mar Biodivers 45(2):157-168

Hulme M, Osborn TJ, Johns TC (1998) Precipitation sensitivity to global warming: comparison of observations with HadCM2 simulations. Geophys Res Lett 25(17):3379-3382

Jain SK, Kumar VI (2012) Trend analysis of rainfall and temperature data for India. Curr Sci (Bangalore) 102:37-49

Jhajharia D, Dinpashoh Y, Kahya E, Singh VP, Fakheri-Fard A (2012) Trends in reference evapotranspiration in the humid region of northeast India. Hydrol Process 26:421-435

Kalra A, Ahmad S (2012) Estimating annual precipitation for the Colorado River Basin using oceanic-atmospheric oscillations. Water Resour Res 48(6):1-24

Kalumba AM, Olwoch JM, Van Aardt I, Botai OJ, Tsela P, Nsubuga FWN, Adeola AM (2013) Trend analysis of climate variability over the West Bank-East London Area, South Africa (19752011). J Geogr Geol 5(4):131

Kendall M (1975a) Multivariate analysis. Charles Griffin, Granville

Kendall MG (1975b) Rank correlation measures. Charles Griffin, Granville, p 220

Khaliq MN, Ouarda TBMJ (2007) On the critical values of the standard normal homogeneity test (SNHT). Int J Climatol 27(5):681-687

Kumar KR, Pant GB, Parthasarathy B, Sontakke NA (1992) Spatial and subseasonal patterns of the long-term trends of Indian summer monsoon rainfall. Int J Climatol 12(3):257-268
Kumar V, Jain SK, Singh Y (2010) Analysis of long-term rainfall trends in India. Hydrol Sci J 55(4):484-496

Kundzewicz ZW, Robson AJ (2004) Change detection in hydrological records - a review of the methodology. Hydrol Sci J 49(1):7-19

Landsea CW, Gray WM (1992) The strong association between western Sahelian monsoon rainfall and intense Atlantic hurricanes. J Clim 5(5):435-453

Liuzzo L, Bono E, Sammartano V, Freni G (2015) Analysis of spatial and temporal rainfall trends in Sicily during the 1921-2012 period. Theor Appl Climatol 126(1):113-129

Mann HB (1945) Nonparametric tests against trend. J Econom Soc 13(3):245-259

Mearns LO, Rosenzweig C, Goldberg R (1996) The effect of changes in daily and interannual climatic variability on CERES-wheat: a sensitivity study. Clim Change 32(3):257-292

Mirza MMQ (2002) Global warming and changes in the probability of occurrence of floods in Bangladesh and implications. Global Environ Change 12(2):127-138

Mirza MQ, Warrick RA, Ericksen NJ, Kenny GJ (1998) Trends and persistence in precipitation in the Ganges, Brahmaputra and Meghna river basins. Hydrol Sci J 43(6):845-858

Mohanty UC, Osuri KK, Pattanayak S, Sinha P (2012) An observational perspective on tropical cyclone activity over Indian seas in a warming environment. Nat Hazards 63:1319-1335

Mondal A, Kundu S, Chandniha SK, Shukla R, Mishra PK (2012) Comparison of support vector machine and maximum likelihood classification technique using satellite imagery. Int J Remote Sens Gis 1(2):116-123

Mondal A, Khare D, Kundu S (2015) Spatial and temporal analysis of rainfall and temperature trend of India. Theor Appl Climatol 122(1-2):143-158

Mondal A, Lakshmi V, Hashemi H (2018) Intercomparison of trend analysis of multisatellite monthly precipitation products and gauge measurements for river basins of India. J Hydrol 565:779-790

Nema MK, Khare D, Adamowski J, Chandniha SK (2018) Spatiotemporal analysis of rainfall trends in Chhattisgarh State, Central India over the last 115 years. J Water Land Dev 36(1):117-128

Pal L, Ojha CSP, Chandniha SK, Kumar A (2019) Regional scale analysis of trends in rainfall using nonparametric methods and wavelet transforms over a semi-arid region in India. Int J Climatol 39(5):2737-2764

Palizdan N, Falamarzi Y, Huang YF, Lee TS, Ghazali AH (2015) Temporal precipitation trend analysis at the Langat River Basin, Selangor, Malaysia. J Earth Syst Sci 124(8):1623-1638

Patra JP, Mishra A, Singh R, Raghuwanshi NS (2012) Detecting rainfall trends in twentieth century (1871-2006) over Orissa State, India. Clim Change 111(3-4):801-817

Pettitt A (1979) A non-parametric approach to the change-point problem. Appl Stat 28(2):126-135

Prabhakar AK, Singh KK, Lohani AK, Chandniha SK (2017) Long term rainfall variability assessment using modified MannKendall test over Champua watershed, Odisha. J Agrometeorol 17(2):288-289

Rind D, Goldberg R, Ruedy R (1989) Change in climate variability in the 21 st century. Clim Change 14(1):5-37

Sabzevari AA, Zarenistanak M, Tabari H, Moghimi S (2015) Evaluation of precipitation and river discharge variations over southwestern Iran during recent decades. J Earth Syst Sci 124(2):335-352

Sen PK (1968) Estimates of the regression coefficient based on Kendall's tau. J Am Stat Assoc 63:1379-1389

Singh P, Kumar V, Thomas T, Arora M (2008) Changes in rainfall and relative humidity in river basins in northwest and central India. Hydrol Process 22(16):2982-2992

Sinha Ray KC, De US (2003) Climate change in India as evidenced from instrumental records. Bull World Meteorol Organ 52(1):53-58 
Sinha Ray KC, Srivastava AK (1999) Is there any change in extreme events like droughts and heavy rainfall. INTROPMET-97 IIT, New Delhi, pp 2-5

Tabari H, Somee BS, Zadeh MR (2011) Testing for long-term trends in climatic variables in Iran. Atmos Res 100(1):132-140

Thiel H (1950) A rank-invariant method of linear and polynomial regression analysis, part 3. Proc Koninalijke Ned Akad Weinenschatpen A 53:1397-1412

Wang Y, Zhou L (2005) Observed trends in extreme precipitation events in China during 1961-2001 and the associated changes in large-scale circulation. Geophys Res Lett 32(9):1-4

Warwade P, Tiwari S, Ranjan S, Chandniha SK, Adamowski J (2018) Spatio-temporal variation of rainfall over Bihar State, India. J Water Land Dev 36(1):183-197
Yu YS, Zou S, Whittemore D (1993) Non-parametric trend analysis of water quality data of rivers in Kansas. J Hydrol 150(1):61-80

Yue S, Hashino M (2003) Temperature trends in Japan: 1900-1996. Theor Appl Climatol 75(1-2):15-27

Yue S, Wang C (2004) The Mann-Kendall test modified by effective sample size to detect trend in serially correlated hydrological series. Water Resour Manag 18:201-218

Zhang Q, Liu C, Xu CY, Xu Y, Jiang T (2006) Observed trends of annual maximum water level and streamflow during past 130 years in the Yangtze River basin, China. J Hydrol 324(1):255-265

Publisher's Note Springer Nature remains neutral with regard to jurisdictional claims in published maps and institutional affiliations. 